\title{
Resenha: \\ Estaria a literatura em perigo?
}

\author{
Anselmo Peres Alós ${ }^{1}$ \\ Juliana Prestes de Oliveira ${ }^{2}$ \\ Amanda Laís Jacobsen de Oliveira ${ }^{3}$
}

Dividida em 7 capítulos, além da apresentação, prólogo e notas, a obra A literatura em perigo (2009), de Tzvetan Todorov, evoca uma pertinente reflexão sobre o modo como a literatura é trabalhada nas salas de aulas (em especial no contexto universitário). Essa abordagem, para ele, é, muitas vezes, apenas uma discussão sobre textos teóricos que abordam determinado texto literário, sem contato efetivo com as obras literárias, ou como pretexto para estudar outro assunto, ou outra disciplina. Algo que acontece no Ensino Básico, no Brasil, uma vez que a disciplina de literatura possui amarras que a condicionam a relatos dos períodos literários e suas características.

Ao pensar nisso, Todorov expõe que a literatura estaria em perigo, uma vez que, segundo Caio Meira (tradutor e autor do prólogo desta obra), o que ocorre não é a falta

[...] de bons poetas ou ficcionistas, o esgotamento da produção ou da criação poética, mas a forma como a literatura tem sido oferecida aos jovens, desde a escola primária até a faculdade: o perigo está no fato de que, por uma estranha inversão, o estudante não entra em contato mediante a leitura dos textos literários propriamente ditos, mas com alguma forma de crítica, de teoria ou de história literária (MEIRA, 2009, p. 10).

A partir disso, somos preparados para os questionamentos que as próximas páginas do texto evocarão, principalmente no que diz respeito ao ensino de literatura e a relação da literatura com a formação humana. Algo muito pertinente para nós, professores de Letras, pois faz raciocinar a respeito do método majoritariamente empregado nas escolas: abordar o que falam os críticos, ao invés de abordar o que falam as obras literárias.

A fim de contextualizar o leitor acerca dos motivos que o levaram a pensar acerca do perigo pelo qual passa a literatura, Todorov inicia seu livro em primeira pessoa, com um acento um tanto autobiográfico. Assim, Todorov assume que sua opção pela análise imanentista foi a única possibilidade que teve de fugir à crítica monológica socialista:

Para ter êxito nos estudos superiores, porém, era preciso redigir, ao final do quinto ano, uma monografia de fim de curso. Como falar de literatura sem ter de me curvar às exigências da ideologia dominante? Tomei um dos raros caminhos em que era possível escapar da militância geral. Essa via consistia em tratar de objetos sem cerne ideológico: ou seja, nas obras literárias, abordar a própria materialidade do texto, suas formas linguísticas (TODOROV, 2009, p. 17).

1 O presente trabalho foi realizado com apoio da Coordenação de Aperfeiçoamento de Pessoal de Nível Superior - Brasil (CAPES) - Código de Financiamento 001. Professor do Departamento de Letras vernáculas e do PPGLetras da Universidade Federal de Santa Maria. Coord. do Projeto "Contaminados, torturados e abjetos: por uma poética do corpo e da subjetividade na América Latina.

2 Doutoranda em Letras Estudos literários pelo PPGLetras da UFSM. Integrante do projeto de pesquisa "Contaminados, torturados e abjetos: por uma poética do corpo e da subjetividade na América latina".

3 Doutoranda em Letras Estudos literários pelo PPGLetras da UFSM. Integrante do projeto de pesquisa "Contaminados, torturados e abjetos: por uma poética do corpo e da subjetividade na América latina". 
Ainda na busca por um espaço em que a literatura, mais especificamente o estudo dela, fosse vista de modo mais aberto, na relação e na aproximação de obras literárias umas com as outras, Todorov rememora seu primeiro encontro com Gérard Genette, que lhe apresentou ao seu futuro orientador de doutorado: Roland Barthes. Nessa fase, Todorov dedicou-se à análise imanente das obras, ao encontro com os autores durante a leitura. Para ele, a literatura está no meio de um conjunto de variados discursos, possuindo diversificadas formas de expressão. A literatura o ajuda a viver: ela é "[m]ais densa e mais eloquente que a vida cotidiana, mas não radicalmente diferente, [...] amplia o nosso universo, incita-nos a imaginar outras maneiras de conhecê-lo e organizá-lo" (TODOROV, 2009, p. 23), ponto inúmeras vezes esquecido pelos estudos literários.

$\mathrm{O}$ autor propõe que seja dada atenção à análise da obra, tanto estrutural quanto de outros modos, buscando compreender os variados sentidos do texto. Ademais, segundo ele, é necessário pensar sobre as obras que julgamos dignas de estudos, pois os textos literários são lidos, pelo público em geral, como uma forma de encontrar uma maneira de entender a si mesmo. Todorov ainda acrescenta que:

[o] conhecimento da literatura não é um fim em si, mas uma das vias régias que conduzem à realização pessoal de cada um. O caminho tomado atualmente pelo ensino literário, que dá as costas a esse horizonte ("nessa semana estudamos metonímia, semana que vem passaremos à personificação"), arrisca-se a nos conduzir a um impasse - sem falar que dificilmente poderá ter como consequência o amor pela literatura (TODOROV, 2009, p. 33, grifo do autor).

Ainda sobre o ensino de literatura, Todorov apresenta como proposta uma abordagem que considera as relações entre os elementos internos à obra e os elementos externos, como contexto histórico, estético e ideológico. Mas ao que parece, nos estudos desenvolvidos em universidades, isso não era - e ainda não é, em muitos casos - levado em conta, causando incômodo a Todorov, pois o ensino universitário desconsidera a literatura como forma de interpretação do mundo, resultando em um ensino básico onde a literatura é ensinada como algo isolado, que não tem relação com nada do mundo, nem mesmo os discursos provenientes da sociedade.

Em seguida, Todorov discorre sobre a literatura contemporânea, elucidando a prática de muitos autores de transformarem a escrita da literatura em "[...] um laboratório no qual o autor pode estudar a si mesmo a seu bel-prazer e tentar se compreender" (TODOROV, 2009 , p. 43), o que resultou no que atualmente "[...] se chama de "autoficção": o autor continua a se dedicar à evocação de seus humores, mas, além disso, se libera de todo constrangimento referencial" (TODOROV, 2009, p. 43). Após essa prática, o autor relata que deixou de atentar para a perspectiva do autor para adotar a do receptor, adentrando no debate acerca do que é $o$ belo. Isso nos faz lembrar das teorias que envolvem as questões da "morte do autor", da estética da recepção e do que é a arte, porém com uma linguagem mais didática e de fácil entendimento.

No decorrer do texto, Todorov remonta a Aristóteles e, consequentemente, ao postulado aristotélico que afirma a necessidade de que a literatura deve ter verossimilhança. Também traz à tona as ideias de Boileau sobre o belo ser o que é verdadeiro, e que apenas o verdadeiro é amável. Toda essa evocação foi feita como forma de orientar o leitor em relação à trajetória dos estudos literários, além do intuito de chegar à questão da literatura não poder ser separada da moral, da política, da religião e da história. 
Todorov ainda acrescenta que, apesar da literatura de imaginação e dos escritos científicos ou filosóficos serem distintos, eles estão dentro de um gênero comum, que “[...] uns e outros dependem do mundo e agem sobre ele, contribuindo assim para a criação de uma sociedade imaginária habitada pelos leitores do passado e pelos leitores do porvir" (TODOROV, 2009, p. 60).

Na sequência, Todorov debate sobre o Romantismo e as Vanguardas. Inicialmente ele comenta sobre as ideias de Baudelaire, Flaubert, Balzac e Oscar Wilde acerca da imaginação, o papel do poeta no mundo e a ideia da "arte pela arte". Com isso, Todorov aponta para o abismo que se criou, na época - e que percebemos a existência ainda hoje -, entre a literatura de elite, a de massa e aquela que fala ou retrata a vida dos menos abastados, principalmente no que diz respeito ao que era estudado na academia. Logo após, o autor discorre sobre o surgimento das vanguardas, em que uma concepção acerca de arte surge, desejando maior liberdade de criação. Percebemos que tais tópicos foram evocados a fim de debater sobre como a arte, hoje em dia, é vista de maneira, muitas vezes, rasa e empobrecida, além de instigar a reflexão ao modo de pensar que considera como arte apenas aquilo que é produzido ou consumido por determinada classe da sociedade.

Interessado em dialogar no tocante ao que pode a literatura, Todorov rememora a leitura de Autobiografia (1873), de John Stuart Mill, nessa obra é narrada sobre sua vida de Mill e sua ligação com os textos literários. Tal introdução foi muito bem pensada e construída, uma vez que Todorov intentava dizer que:

[A] literatura pode muito. Ela pode nos estender a mão quando estamos profundamente deprimidos, nos tornar ainda mais próximos dos outros seres humanos que nos cercam, nos fazer compreender melhor o mundo e nos ajudar a viver. Não que ela seja, antes de tudo, uma técnica de cuidados para com a alma; porém, revelação do mundo, ela pode, também, em seu percurso, nos transformar a cada um de nós a partir de dentro. A literatura tem um papel vital a cumprir; mas para isso é preciso tomá-la no sentido amplo e intenso que prevaleceu na Europa até fins do século XIX e que hoje é marginalizado, quando triunfa uma concepção absurdamente reduzida do literário (TODOROV, 2009, p. 76-77).

$\mathrm{O}$ autor acrescenta ainda que ela, a literatura, retrata o nosso mundo, os pensamentos e conhecimentos do nosso mundo psíquico e social, buscando compreender a nossa experiência humana. A partir disso, acreditamos na pertinência da proposta sugerida por Todorov relativa ao modo de abordagem e trabalho com a literatura em sala de aula.

Outrossim, a literatura, segundo Todorov, é algo capaz de incitar o leitor a pensar, formular uma tese quanto ao que a obra expõe, permitindo que esse possa ser mais ativo diante da obra e do mundo. Além do mais, os enredos são capazes de produzir os mais diversos sentidos, desestabilizando nossos conhecimentos prévios, ampliam a nossa aptidão interpretativa e capacidade de associação e "provocam um movimento cujas ondas de choque prosseguem por muito tempo depois do contato inicial" (TODOROV, 2009, p. 78).

Os pontos supramencionados, sinalizados por Todorov, tal como o fato da literatura proporcionar o contato com discursos diversos e cosmovisões diversas, faz-nos pensar que ela não elabora um sistema de leis rigorosas a serem seguidas. Pelo contrário, ela permite que vozes distintas sejam ouvidas. Sendo assim, há a chance de acessarmos o outro e, dessa forma, termos mais empatia com aqueles que são diferentes de nós, tornando-nos mais humanos. Ao enunciar que: 
Pensar e sentir adotando o ponto de vista dos outros, pessoas reais ou personagens literárias é o único meio de tender à universalidade e nos permitir cumprir nossa vocação. É por isso que devemos encorajar a leitura por todos os meios - inclusive a dos livros que o crítico profissional considera com condescendência, se não com desprezo, desde Os três mosqueteiros até Harry Potter: não apenas esses romances populares levaram ao hábito da leitura milhões de adolescentes, mas, sobretudo, lhes possibilitaram a construção de uma primeira imagem coerente do mundo, que, podemos nos assegurar, as leituras posteriores se encarregarão de tornar mais complexas e nuançadas (TODOROV, 2009, p. 82, grifos do autor).

Todorov instiga-nos e repensar o modo tradicional que a literatura é ensinada e o nosso apego ao cânone, que resulta em preconceitos com obras mais populares ou da margem. Outro ponto utilizado pelo autor, para enfatizar a questão do que pode a literatura, são as cartas trocadas entre Flaubert e Sand, nas quais os autores discutem as suas respectivas concepções de literatura, exemplo utilizado de forma muito ilustrativa e didática, facilitando o entendimento da temática. A partir dessa concepção (melhor entendimento da condição humana, ajudando, assim, a transformar cada leitor), e das reflexões desenvolvidas até então, Todorov afirma que, em sala de aula, as análises das obras deveriam focar nos sentidos presentes no texto, pois, desse modo, conduziria os leitores ao conhecimento do humano.

Se a visão de Todorov, apresentada até o momento, fosse aplicada com mais frequência, no Brasil, acreditamos que poderia haver mais humanidade e alteridade em nossa sociedade, uma vez que:

Sendo o objeto da literatura a própria condição humana, aquele que a lê e a compreende se tornará não um especialista em análise literária, mas um conhecedor do ser humano. Que melhor introdução à compreensão das paixões e dos comportamentos humanos do que uma imersão na obra dos grandes escritores que se dedicam a essa tarefa há milênios? [...] que melhor preparação pode haver para todas as profissões baseadas nas relações humanas? (TODOROV, 2009, p. 92-93).

Assim, do início ao fim de sua obra, de maneira coerente e com linguagem de fácil entendimento, Todorov tira-nos de nossa zona de conforto acerca do modo como vemos a literatura e a abordamos, seja no ensino dela ou em nossas pesquisas, e faz com que repensemos nossas práticas, sejamos nós professores do Ensino Básico, pesquisadores universitários, ou leitores de fim de semana.

\section{Referências}

MEIRA, Caio. Apresentação à edição brasileira. In: TODOROV, Tzvetan. A literatura em perigo. Trad. Caio Meira. Rio de Janeiro: DIFEL, p. 9-12, 2009.

TODOROV, Tzvetan. A literatura em perigo. Rio de Janeiro: DIFEL, 96 p, 2009. Tradução de Caio Meira 